\title{
Property in a shrinking planet: fault lines in international human rights and investment law
}

\author{
Lorenzo Cotula*
}

\begin{abstract}
Long at the margins of international law, property is now among the key challenges facing international law-and decision-makers. A 'shrinking' planet and a polycentric international law regime provide the backdrop for contestation between different property concepts and claims. While presenting important commonalities in legal concepts and normative content, international investment law and international human rights law protect different and possibly competing rights, reflect different balances of commercial and non-commercial considerations, and embody different standards of legal protection. As the frontiers of natural resource extraction expand, natural resource investments can bring different property concepts and claims directly into tension. In this context, the articulation between investment law and human rights law influences the ways in which international law mediates competition for the world's natural resources, redefining the balance between public and private interests and reshaping spaces for the lawful exercise of state sovereignty.
\end{abstract}

\section{Framing the issue}

Property has been important in the historical development of international law. Early international lawyers used property concepts such as terra nullius to legitimise the colonial appropriation of land and territories. International law has built on property notions in more recent times too, for example in fisheries (Barnes, 2009). Contemporary norms regulating the acquisition of territory partly draw on property law concepts (Lesaffer, 2005). A small but significant jurisprudence addresses the relationship between establishing sovereignty and acquiring property (Ederington, I997). The international law on the protection of foreign property dates back to the nineteenth century, and so do early treaties to harmonise intellectual property laws. Yet for a long time discussions about property remained relatively marginal in international law, as property fell primarily within the exclusive domain of national jurisdiction.

Developments in recent decades have brought property to the fore in international legal practice and scholarship. Increased economic interdependence has as its mirror image that of a shrinking planet. Global consumption is reshaping expectations of returns from natural resource investments, and placing the world's natural resources under unprecedented pressure: petroleum and minerals are being extracted in previously marginal sites, and agribusiness developments are expanding to new terrains. As natural resource extraction expands and intensifies, property broadly defined here as the legal arrangements regulating control over valuable resources becomes an increasingly contested terrain. And as foreign investments in plantation agriculture or extractive industries enhance the transnational dimensions of property relations, international means of regulation acquire new importance.

* Principal Researcher in Law and Sustainable Development, International Institute for Environment and Development (IIED), Edinburgh. Email: lorenzo.cotula@iied.org 
Indeed, international law-making affecting property has accelerated in recent decades. New international regimes have been devised to regulate the appropriation of resources previously beyond human reach. New treaties and greater recourse to international remedies are reshaping spaces for the exercise of state sovereignty. And soft-law instruments are making inroads into areas where international law-makers would traditionally not venture: the Voluntary Guidelines on the Responsible Governance of Tenure of Land, Fisheries and Forests in the Context of National Food Security, endorsed in 2012 by the United Nations Committee on World Food Security, provide international guidance on land tenure - traditionally an issue falling squarely within the exclusive preserve of domestic jurisdiction.

Developments in international human rights law (IHRL) and international investment law (IIL) vividly illustrate the role of property, and of pressures on natural resources, in international law. In recent years, a large number of investment treaties and arbitrations, and rapidly expanding scholarly writing, have made IIL one of the most dynamic branches of international law. While IIL covers diverse assets and sectors, property protection and natural resource investments remain core concerns. In fact, some early drafting (such as the I967 Draft Convention on the Protection of Foreign Property of the Organisation for Economic Co-operation and Development) and scholarship (e.g. Christie, I963; Nicholson, 1965; Dolzer, I986) framed IIL in property terms. Property concepts then went out of fashion, but recent scholarship suggests that a comeback might be underway (Douglas, 2009, 20I4; Cotula, 20I2). The concept of property was central in some recent investor-state arbitrations. ${ }^{{ }^{2}}$ Investments in extractive industries and agriculture account for an important share of arbitral case-load (ICSID, 2013).

Property and natural resources have also been at the centre of important developments in IHRL. Indigenous peoples have mobilised IHRL bodies to protect their rights to natural resources, including against encroachment from natural resource investments. Peasant movements are campaigning to obtain international recognition for peasants' land rights, with concerns about 'land grabbing' by agribusiness companies having strengthened their resolve. United Nations Special Rapporteurs have clarified the property implications of several human rights, for example as access to land and natural resources can be instrumental in realising the right to food (De Schutter, 2008, 2009). And while in the early I990s a United Nations Independent Expert concluded that international law did not recognise a universal right to property (Valencia Rodríguez, I993), some academics are now arguing for the existence of such a right (Sprankling, 20I4).

These multiple developments have tended to increase the relevance of property in international law. Unlike other bodies of international law, IHRL and IIL provide private actors with international redress in relation to property claims, reconfiguring relations between sovereign states and private rights. At the same time, as direct expropriations have declined since the I97os, and regulation has become the main source of government interference with property, disputes over property have become more complex and affect a wider range of government measures, with far-reaching consequences for the exercise of sovereign powers. IHRL and IIL address property issues in different ways, partly because they pursue different objectives, protect different interests, and reflect different ways to conceptualise property. The growing commercial pressures on the world's natural resources bring into tension these different property concepts and claims.

This paper examines the protection of property under IHRL and IIL, and its implications for the role of international law in addressing commercial pressures on land and resources. The concern explored in the paper is whether, as pressures on resources increase, international law disadvantages the world's poorest and most marginalised people. Part II locates property in

I Emmis International Holding B.V., Emmis Radio Operating B.V. and MEM Magyar Electronic Media Kereskedelmi és Szolgáltató Kft. v. Hungary, Award, I 6 April 20I4, ICSID ARB/I 2/2; Bayview Irrigation District and Others v. United Mexican States, Award, I9 June 2007, ICSID ARB(AF)/05/r. 
international law, discussing the relationship between property and sovereignty, and taking a perspective rooted in history and jurisprudence. Part III explores the polycentric nature of the international protection of property, charting the forces that push towards convergence or divergence within IHRL and within IIL. Part IV analyses the relationship between IHRL and IIL. While displaying important commonalities, IHRL and IIL pursue different goals, protect different rights, and reflect different balances of commercial and non-commercial dimensions. They also embody different standards of legal protection. Part V illustrates practical implications for encounters and collisions between the natural resource rights of indigenous peoples and rural communities, and natural resource concessions granted to foreign investors. The conclusion (Part VI) discusses possible ways forward, and calls for greater citizen debate on the evolving international law on the protection of property.

\section{The nexus between property and sovereignty in international law}

Property and sovereignty - considered here as legal rather than sociopolitical or philosophical constructs - are closely connected. To frame this relationship, it is necessary to go back in time: the property-sovereignty nexus is historically determined, and its configuration is the product of legal evolutions over centuries. In Europe, developments between the fourteenth and seventeenth centuries led to the emergence of two key features of today's international legal system. The first is the establishment of state sovereignty as a pillar of international law. Important legal milestones in that process included the dispute between Robert, King of Naples, and Emperor Henry VII in the early I300s, in which several 'consilia' and the papal bull Pastoralis Cura challenged the supremacy of the Holy Roman Empire over kingdoms and princedoms (Pennington, I993); and the Peace of Westphalia of I648, which is conventionally celebrated as the moment where the remnants of a medieval order involving claims of supranational authority were dismantled (Schrijver, 2000). The centrality of state sovereignty in current international law is affirmed in Article 2(I), (4) and (7) of the I945 Charter of the United Nations, in the I970 United Nations Declaration on Principles of International Law Concerning Friendly Relations and Cooperation among States and, with specific regard to natural resources, in General Assembly Resolution 1803 of 1962.

The second relevant feature of contemporary international law is the separation between sovereignty and property: 'property rights are fundamentally independent of state sovereignty and, hence, changes in [...] sovereignty [...] do not affect them' (Ederington, I997, p. 267). Property and sovereignty were closely intertwined under feudal regimes, as the grant of land by lords to vassals came with obligations of political and military allegiance. So in Europe the decline of feudalism played an important part in dissociating property from sovereignty. Colonisation, particularly from the seventeenth century, when transitions from feudalism were well advanced, was the vehicle through which these conceptions of sovereignty and property were exported outside Europe, although in establishing sovereignty over new territories colonial powers often also claimed ownership of land, dispossessing the natives.

While separate, property and sovereignty remain interrelated. The allocation, regulation and administration of property are important attributes of state sovereignty. Research shows how states may allocate property to consolidate their control over marginal parts of the national territory (Lund, 20IIa): by allocating rights to land and resources, governments may reassert control over areas until then left to local management systems. In this sense, property contributes to the construction of effective sovereignty. But there are also tensions between property and sovereignty, because the protection of property can limit the lawful exercise of state sovereignty. This notion has been discussed in Western jurisprudence since the seventeenth century, including in connection with Locke's ideas that the acquisition of property through labour is a natural right 
preceding statehood, and that the protection of property constitutes a key function of the exercise of sovereign powers (Locke, 20I0 [I689]). The affirmation of the right to property as a 'natural and imprescriptible' human right in Article 2 of the French Declaration of the Rights of Man and the Citizen of 1789 embodied similar ideas into a legal document (Sprankling, 20I4).

This construction of property as imposing limits on the exercise of sovereign powers is evident in recent international legal developments. Over the past few decades, the growing interdependence of states and the increasingly blurred lines between a state's internal affairs and matters of global concern have profoundly changed the notion of state sovereignty. International law has extended its reach to issues previously left to national law, and the effectiveness of its regulation and enforcement has increased, particularly in economic relations (Faundez, 20I0). The emergence of private international governance arrangements is questioning the traditional role of states, and of international law, as the sole or even main sites of international regulation (Sassen, 2000). The result is not merely an 'erosion' of state sovereignty, but a fundamental transformation of the form of sovereignty - away from a Westphalian model centred on nation states, and towards a reconfiguration of sovereignty that recognises the multiple sites of regulation in a globalised economy (Jayasuriya, I999).

Developments in the protection of property under IHRL and IIL have been central to these evolutions. Developments in IHRL have clarified the normative content of human rights relevant to the protection of property (the right to property, but also the right to food, peoples' right to dispose freely of their natural resources, or the rights of indigenous peoples over their ancestral territories), and have consolidated monitoring and enforcement through United Nations bodies and, at the regional level, human rights courts including the European Court of Human Rights (ECtHR), the Inter-American Court of Human Rights (IACtHR) and the African Court of Human and Peoples' Rights (ACtHPR). As to IIL, hundreds of bilateral and regional investment treaties, including investment chapters in broader trade and investment treaties, regulate the exercise of sovereign powers in relation to foreign investment. These treaties establish substantive protection standards, such as restrictions on expropriations and requirements that investments be treated in a 'fair and equitable' way, and typically allow investors to take alleged violations to investor-state arbitration. ${ }^{2}$

By setting minimum standards of substantive protection and providing international redress mechanisms, IHRL and IIL protect private rights against adverse state conduct. In this sense, they redefine the parameters for the lawful exercise of sovereign powers: states can lawfully take measures that encroach on protected property only if certain conditions are met. As pointed out by an arbitral tribunal in its discussion of an alleged expropriation, 'while a sovereign State possesses the inherent right to regulate its domestic affairs, the exercise of such right is not unlimited and must have its boundaries. [...] [T] he rule of law, which includes treaty obligations, provides such boundaries.'3

2 Investment treaties protect investment, rather than property, and investment is typically defined broadly to encompass a wide range of assets. Therefore, not all investment constitutes property. Equally, not all property constitutes investment, which in common parlance is usually taken to require a capital contribution for economic activities involving the taking of risks to generate returns (Douglas, 20I4). Some arbitral jurisprudence has elaborated on these characteristics of investment, particularly in arbitrations under the I 965 International Convention on the Settlement of Investment Disputes between States and Nationals of Other States (ICSID Convention). But only a few investment treaties explicitly mention these characteristics. The fact that many treaty definitions focus on 'assets', rather than the running of a business enterprise, would tend to increase the convergence between the notions of property and investment (see Douglas, 20I4). Investor rights to natural resources are often based on state contracts, yet these long-term resource concessions present proprietary features, for instance excludability, and often a degree of transferability.

3 ADC Affiliate Limited and ADC \& ADMC Management Limited v. Republic of Hungary, Award, 2 October 2006, ICSID ARB/o3/I6, para. 423. 
It would be simplistic to frame the property-sovereignty nexus as a zero-sum game, where stronger property protection automatically translates into corresponding limitations of sovereignty. International law is largely founded on state consent, so its reconfiguring sovereignty occurs through state commitments that are in themselves a manifestation of sovereignty. ${ }^{4}$ States remain the central actor in the negotiation and implementation of treaties that protect property. Effective exercise of sovereignty is a precondition for states to be able to protect property within their jurisdiction. Further, states still can and often do exercise naked power in direct violation of international law. There should be no illusion about the power of right to stem arbitrary manifestations of might. But legal norms shape space for lawful state conduct. And where mechanisms to sanction unlawful interferences with property are effective, international law can impose real discipline on the exercise of state sovereignty.

In some continuity with the colonial era, when establishing control over natural resources was an important driver of the European exportation of notions of property and sovereignty, struggles over natural resources have been central to the development of the international norms defining the boundaries between property and sovereignty. In IIL, this is illustrated by the tensions, in the I960s and I970s, between the international recognition of permanent sovereignty over natural resources and the protection of foreign investment, and more recently by the numerous investorstate arbitrations triggered by a wave of resource nationalism. ${ }^{5}$ In IHRL, the important place of natural resources in contestation over property is illustrated by cases brought by indigenous peoples to protect or advance their rights to ancestral lands. ${ }^{6}$

Sixty years ago, the conceptual commonalities between IHRL and IIL as bodies of international law protecting private actors against arbitrary state action appeared close to providing the foundations for the development of a uniform international regime for the protection of property. Until that point, debates on the international law protection of property had focused on foreign property, opposing capital-exporting countries advocating for international minimum standards of protection and capital-importing countries arguing that foreign investment should only be entitled to the same treatment applicable to nationals under domestic law. In I955, a few years after the Universal Declaration of Human Rights (UDHR) introduced international recognition for the human right to property, the first Special Rapporteur on State Responsibility of the International Law Commission (ILC), Francisco García-Amador, argued that this debate could now be superseded by interpreting the minimum standard of protection as consisting of internationally recognised human rights available to both nationals and non-nationals, including the right to property (García-Amador, I955). The human right to property would provide the same level of international protection to both foreign investors and local nationals. Two years later, the Special Rapporteur proposed a draft text along these lines.7

4 See S.S. Wimbledon (U.K. v. Japan), I7 August I923, P.C.I.J. (ser. A) No. I, at 25; and Texaco Overseas Petroleum Company and California Asiatic Oil Company v. The Government of the Libyan Arab Republic, Award, I 9 January I977, 53 ILR 389, paras. 66-68.

5 E.g. Sergei Paushok, CJSC Golden East Company and CJSC Vostokneftegaz Company v. Government of Mongolia, Award on Jurisdiction and Liability, 28 April 20II, arbitration under the Arbitration Rules of the United Nations Commission on International Trade Law (UNCITRAL); Burlington Resources Inc. $v$. Republic of Ecuador, Decision on Liability, I4 December 2012, ICSID ARB/08/5.

6 E.g. Mayagna (Sumo) Awas Tingni Community v. Nicaragua, Judgment, 3I August 200I, IACtHR; Yakye Axa Indigenous Community v. Paraguay, Judgment, I7 June 2005, IACtHR; Sawhoyamaxa Indigenous Community v. Paraguay, Judgment, 29 March 2006, IACtHR; Saramaka People v. Suriname, Judgment, 28 November 2007, IACtHR.

7 'The State is under the duty to ensure to aliens the enjoyment of the same civil rights, and to make available to them the same individual guarantees as are enjoyed by its nationals. These rights and guarantees shall not, however, in any case be less than the fundamental human rights recognized and defined in contemporary 
García-Amador's focus on the treatment of 'aliens' proved controversial. Subsequent rapporteurs shifted the focus of what would become the Articles on Responsibility of States for Internationally Wrongful Acts to the rules governing state responsibility in general. Application of human rights safeguards to corporate entities has not been without critics (Scolnicov, 2013). But the point here is that García-Amador's unifying approach to the international regime for the protection of property was not taken up. Over the past sixty years, IHRL and IIL have developed important points of contact, for example where arbitral tribunals have drawn on ECtHR jurisprudence. ${ }^{8}$ But evolutions in IHRL and IIL have made the international law on the protection of property more, not less, fragmented: there are significant differences in the philosophical underpinnings and normative content shaping the protection of property both within and between IHRL and IIL, creating variable spaces for the lawful exercise of state sovereignty.

In addition, the boundaries between property and sovereignty have continued to shift over time. Under both IHRL and IIL, states have consented to treaties that restrict their exercise of sovereign powers, but have also reclaimed sovereign space when they felt that international tribunals interpreted treaties in ways they would not support. For example, arbitral interpretations of investment treaty provisions on expropriation and fair and equitable treatment led some states to use more restrictive wording in subsequent treaties. 9 In completely different settings, the jurisprudence of regional human rights bodies in the Americas triggered political backlashes and government calls for 'reform' (Krohnke, 20I3; Shelton, 20I4), while a landmark decision condemning land seizures in Zimbabwe led states effectively to disband the Tribunal of the Southern African Development Community (SADC) (Nathan, 2013).

The international law affecting the interface between property and sovereignty is highly polycentric and subject to multidirectional shifts over time, with important implications for the ways in which the law regulates encounters between the land and resource rights of indigenous peoples and rural communities, and natural resource concessions granted to foreign investors.

\section{Anatomy of property protection: a polycentric international law regime}

Under customary international law, states have the sovereign right to regulate and expropriate assets within their jurisdiction. But where foreign property is at stake, expropriations must comply with minimum conditions, including public purpose and payment of compensation. ${ }^{\text {Io }}$ These customary rules on the protection of foreign property were already crystallised at the turn of the twentieth century (Dupuy, 2009). In contrast, the IHRL protection of property only emerged after World War II, and there is less consensus on any customary norms concerning the expropriation of assets held by nationals. Beyond customary rules, the international norms on the protection of property depend on applicable treaties. The important role of treaties and diversity in treaty

international instruments' (art. 5(I)). Art. 6 clarified that such 'fundamental human rights' include the 'right to own property': UN Doc A/CN.4/I06, in YBILC I957 (II), pp. I04-I30.

8 E.g. Técnicas Medioambientales Tecmed, S.A. v. United Mexican States, Award, 23 May 2003, ICSID ARB(AF)/oo/2, paras. I22-I23; Azurix Corp. v. Argentine Republic, Award, I4 July 2006, ICSID ARB/oI/I2, paras. 3I I-3I2; Ronald S. Lauder v. Czech Republic, Final Award, 3 September 200I, UNCITRAL, para. 200.

9 See e.g. the US Model BITs of 2004 and 20I2, art. 5 (linking fair and equitable treatment to the minimum standard of treatment under customary international law) and Annex B (clarifying the boundaries of indirect expropriation).

Io German Interests in Polish Upper Silesia (Merits) (Germany v. Poland), Judgment, 25 May I926, P.C.I.J. Ser A No. 7 , at 20-24; Amoco International Finance Corp. v. Islamic Republic of Iran and Others, Partial Award, I4 July I987, I5 Iran-US C.T.R. I89, paras. II3-I I7; Compañia del Desarrollo de Santa Elena SA v. Republic of Costa Rica, Final Award, I7 February 2000, 39 ILM (2000) I317, para. 7I. See also Reinisch (2008, pp. 173-176) and UNCTAD (2012, p. 27). 
formulation and ratification underpin significant variation in the international rules applicable to the protection of property, both within and between IHRL and IIL. I will start by examining convergence and divergence within IIL and within IHRL, outlining systemic considerations that abstract - for a moment - from my primary concern about pressures on land and natural resources.

IIL is largely based on a 'spaghetti bowl' of numerous bilateral and regional treaties. The content of investment treaties presents important similarities. In addition, the most-favoured-nation clauses contained in most investment treaties tend to level the playing field upwards, because two investments operating in the same host state but covered by different treaties would in principle be entitled to the same, more favourable, treatment provided by either or a third treaty concluded by the host state. In effect, most-favoured-nation clauses promote the multilateralisation of IIL (Schill, 2009). Nevertheless, differences in the protection standards applicable under different treaties remain, including given diversity of treaty formulations and given emerging trends to frame most-favoured-nation clauses in ways that limit the importation of standards from other investment treaties. ${ }^{\text {II }}$ As a result, although IIL constitutes a coherent field of study and practice, protection standards vary, depending on applicable treaties.

Investment treaty clauses on indirect expropriation illustrate this diversity of treaty formulations. 'Indirect expropriation' refers to regulation that, without transferring ownership, interferes with property to such an extent that the property 'must be deemed to have been expropriated'. ${ }^{12}$ One important issue for the property-sovereignty nexus concerns defining the boundaries between non-compensable regulation and indirect expropriation requiring compensation. Many investment treaties provide no guidance on how to determine whether an indirect expropriation has occurred: they merely define the conditions for the legality of expropriations (usually payment of compensation at specified standards, public purpose, non-discrimination and due process, or variations of these), and apply these conditions to both direct and indirect expropriations. ${ }^{13}$

On the other hand, some recent investment treaties contain language developed as a response to arbitral jurisprudence awarding damages to investors for losses suffered as a result of regulation. For example, investment treaties concluded by the US and by Canada with several states include an annex clarifying that, as a general rule, non-discriminatory, public-interest regulation does not constitute indirect expropriation, and indicating the factors to consider when assessing whether an indirect expropriation has occurred. ${ }^{\mathrm{I}}$ The ASEAN Comprehensive Investment Agreement (ACIA) of 2009 contains a comparable annex presenting more restrictive language and somewhat different factors. ${ }^{15}$ The fact that some other states continue to conclude treaties not featuring similar annexes might be interpreted as a deliberate choice not to apply these clarifications. Therefore, while the 'right to regulate' is part of customary international law, and exists even if not explicitly mentioned in investment treaties, the different formulations of expropriation

I I Art. I9(I) of the COMESA (Common Market for Eastern and Southern Africa) Investment Agreement of 2007. See also art. 4.4 of the SADC Model Investment Treaty of 2012 and the approach proposed by the European Commission for the Transatlantic Trade and Investment Partnership (Consultation Document, March 20I4, online: 〈http://trade.ec.europa.eu/doclib/docs/20I4/march/tradoc_I52280.pdf 〉). Several treaties now limit the importation of more advantageous procedural provisions.

I 2 Starrett Housing Corp. v. Iran, Interlocutory Award, I9 December 1983, 4 Iran-US CTR I22, para. I54.

I3 E.g. France-Uganda BIT 2003, art. 5(2); Colombia-Switzerland BIT 2006, art. 6; and India-Myanmar BIT 2008, art. 5 .

I4 E.g. Annex B of the Rwanda-US BIT 2008 and Annex I of the Benin-Canada BIT 2013.

I5 Contrast ACIA Annex 2, requiring breach of a government's 'prior binding written commitment to the investor' (art. 3(b)), and Rwanda-US BIT 2008, referring more generally to interference with 'reasonable investment-backed expectations' (art. 4(a)(ii)). The latter does not necessarily involve written commitments through a tailored binding instrument, as is required by ACIA. 
clauses and related annexes (where these apply) affect the exact contours of that right: depending on applicable treaties, arbitral tribunals could reach different conclusions on the boundaries between expropriation and regulation.

Some features of investor-state arbitration compound diversity of interpretive approaches in IIL, including lack of appellate mechanisms or binding precedent. Other features promote uniformity, including a relatively small group of repeat arbitrators and the fact that, in practice, arbitral tribunals do cite earlier awards. On several legal issues, there is now relative consistency in arbitral jurisprudence. For example, while arbitral tribunals have formulated in different ways the test to determine whether an indirect expropriation has occurred, they have often required a 'substantial' deprivation or impact. ${ }^{16}$ However, arbitral jurisprudence in important areas is inconsistent. For example, when establishing whether an indirect expropriation has occurred, tribunals have taken different positions on whether the public-purpose and non-discriminatory nature of measures can be considered. ${ }^{17}$ There are even well-known examples of contrasting outcomes in disputes rooted in the same facts. ${ }^{18}$

The IHRL protection of property also presents a degree of internal differentiation, largely as a result of three interlinked factors. The first is that, more than IIL, IHRL presents considerable internal ideological diversity, reflected in the multiple human rights relevant to the protection of property. For example, while the right to property ${ }^{\mathrm{I} 9}$ is a cornerstone of the liberal political tradition and has historically emerged with an emphasis on individual rights, peoples' right to freely dispose of their natural resources ${ }^{20}$ is rooted in developing country demands for a more equitable world economic order, and is an inherently collective right. Socio-economic rights such as the rights to food and to housing, and the international protection of the natural resource rights of indigenous peoples, have yet different historical, philosophical and political roots.

These diverse genealogies problematise the assumptions often made about human rights law being purely a Western construct. The diversity is also reflected in the multiple ways in which human rights are used. While the right to property has sometimes been used to resist publicpurpose regulation or redistributive reforms, ${ }^{21}$ and as such has been regarded by some as a 'conservative' human right, peoples' right to freely dispose of their natural resources emphasises social emancipation, ${ }^{22}$ and tensions between different property-relevant human rights cannot be ruled out. As will be discussed, however, IHRL jurisprudence has also articulated the collective and emancipatory dimensions of the right to property.

I6 E.g. Pope \& Talbot Inc v. Government of Canada, Interim Award, 26 June 2000, UNCITRAL, para. I02; CMS Gas Transmission Company v. Argentine Republic, Award, I2 May 2005, ICSID ARB/or/8, paras. 262-264; Telenor Mobile Communications A.S. v. Republic of Hungary, Award, I3 September 2006, ICSID ARB/04/I5, paras. 6465; Chemtura Corporation v. Government of Canada, Award, 2 August 20Io, UNCITRAL, paras. 244-249.

I7 The main approaches are the 'sole effects' doctrine, the 'police powers' doctrine and a proportionality test inspired by ECHR jurisprudence.

I 8 Contrast Lauder v. Czech Republic, supra note 8; and CME Czech Republic B.V. v. Czech Republic, Partial Award, I 3 September 200I, UNCITRAL.

I9 Art. I7 of the UDHR and several regional instruments, discussed below.

20 Art. I of both the International Covenant on Civil and Political Rights (ICCPR) and the International Covenant on Economic, Social and Cultural Rights; art. 2 I of the African Charter on Human and Peoples' Rights.

2 I E.g. James and Others v. United Kingdom, Judgment, 2I February I986, 8 European Human Rights Reports (EHRR) I23; Holy Monasteries v. Greece, Judgment, 9 December I994, ECtHR, 20 EHRR I.

22 See Social and Economic Rights Action Centre and Center for Economic and Social Rights v. Nigeria, 27 October 200I, African Commission on Human and Peoples' Rights, (200I) African Human Rights Law Reports (AHRLR) 60, paras. 55-58; Centre for Minority Rights Development and Minority Rights Group on behalf of Endorois Welfare Council v. Kenya, 25 November 2009, African Commission on Human and Peoples' Rights, paras. 252-268. 
The second factor shaping differentiation within IHRL is geographic, concerning the importance of regionalism. The right to property is affirmed in the UDHR but not in the International Covenant on Civil and Political Rights (ICCPR) and the International Covenant on Economic, Social and Cultural Rights (ICESCR). Therefore, the IHRL protection of property importantly depends on regional human rights systems. As a result, it is subject to variation in the coverage and effectiveness of these systems. Europe and the Americas have effective regional human rights systems involving binding treaties and international recourse. In Southeast Asia, regional mechanisms are significantly less effective: the recently established ASEAN regional human rights system is centred on the non-binding ASEAN Human Rights Declaration of 2012 and an ASEAN Inter-Governmental Commission on Human Rights with limited powers and independence. In Africa, the African Charter on Human and Peoples' Rights (ACHPR) is legally binding, but only about half of Africa's states have ratified the 1998 Protocol on the Establishment of an African Court on Human and Peoples' Rights. Therefore, the African Commission on Human and Peoples' Rights, which issues authoritative but non-binding decisions, remains the only continental IHRL body available in many African countries. Important parts of Asia and Oceania are not covered by effective regional human rights systems.

Where regional human rights systems exist, they embody diverse balances among human rights rooted in different political and intellectual traditions - another driver of geographic differentiation. For example, the ACHPR places particular emphasis on collective rights, including peoples' right to freely dispose of their natural resources. ${ }^{23}$ In the European and American regional systems, this right is absent, collective rights are less prominent, and the right to property provides the main normative reference for the protection of property.

Moreover, different regional systems protect the same human right in different ways. Take the right to property. This right is affirmed in the main regional systems, including Article I of Protocol I of the European Convention on Human Rights (ECHR); ${ }^{24}$ Article 2I of the American Convention on Human Rights (ACHR); and Article I4 of the ACHPR. There are strong commonalities among these provisions, and regional human rights bodies have referred to each other's right-to-property jurisprudence. ${ }^{25}$ But there are also important differences in treaty formulation and jurisprudence. For example, the ECtHR has consistently applied the right to property to commercial assets held by corporations. ${ }^{26}$ In the Americas, on the other hand, there has been greater caution in hearing cases brought by corporations, ${ }^{27}$ and the IACtHR has

23 Art. 2 I of the ACHPR. See Social and Economic Rights Action Centre and Center for Economic and Social Rights v. Nigeria, supra note 22, paras. 55-58; Centre for Minority Rights Development and Minority Rights Group on behalf of Endorois Welfare Council v. Kenya, supra note 22, paras. 252-268.

24 While Protocol I protects 'peaceful enjoyment of possessions', the ECtHR has interpreted this expression as equivalent 'in substance' to the right to property: Marckx v. Belgium, Judgment, I3 June I979, 2 EHRR 330, para. 63.

25 See e.g. Centre for Minority Rights Development v. Kenya, supra note 22, paras. I74-238 (citing several ECtHR and IACtHR cases).

26 Pine Valley Developments Ltd and Others v. Ireland, Judgment, 29 November I 99I, I4 EHRR 3 I 9; Matos e Silva Lda and Others v. Portugal, Judgment, I6 September I996, 24 EHRR 573.

27 The Inter-American Commission on Human Rights declared inadmissible a petition brought by a company, holding that the ACHR only protects natural persons: Mevopal SA v. Argentina, I I March I999, Report 39/99, para. I7. The Inter-American Court took a more nuanced approach in Cantos v. Argentina, Judgment (Preliminary Objections), 7 September 2001, paras. 27, 29-a case brought by an individual in relation to government actions affecting his business enterprises. IACtHR cases brought by individuals and including right-to-property aspects relating to business activities include Ivcher Bronstein v. Peru, Judgment, 6 February 200I, paras. II7-I3I; and Chaparro Álvarez y Lapo Íñiguez v. Ecuador, Judgment, 2I November 2007, paras. I73-2I 8. 
developed important jurisprudence on the collective right to property of indigenous peoples, placing particular emphasis on spiritual and cultural dimensions. ${ }^{28}$

The third factor shaping differentiation within IHRL concerns the fact that IHRL establishes special protections for particular groups - for example, the rights to land and natural resources of indigenous peoples, recognised in Articles I3-19 of the 1989 Convention Concerning Indigenous and Tribal Peoples in Independent Countries, and Articles 25-30 of the 2007 United Nations Declaration on the Rights of Indigenous Peoples. Involvement of indigenous peoples has also influenced the interpretation of generally applicable treaties: IHRL bodies have held that the public-purpose requirement for expropriation involves a higher threshold for indigenous land. ${ }^{29}$

Like IIL, IHRL is a coherent field of study and practice, but also a polycentric system containing forces promoting both convergence and divergence. It embodies protection standards that vary considerably depending on where a property is, who it belongs to and which rights can be claimed, delineating variable shapes in the relationship between property and sovereignty. Having discussed the protection of property under IIL and IHRL, I now turn to exploring convergence and divergence between IIL and IHRL, and to relating findings to the property-sovereignty nexus and to commercial pressures on natural resources.

\section{Convergence and divergence between IHRL and IIL}

There has been much debate about the relationship between IHRL and IIL. Scholars have compared IHRL and IIL approaches for dealing with similar issues (Kriebaum and Schreuer, 2007), and drawn insights for theoretical debates about unity and fragmentation of international law (Dupuy, 2009). Some literature emphasises the commonalities between IHRL and IIL (Dupuy, 2009; Francioni, 2009), including the common concern about protecting private actors against arbitrary state action and parallels in normative content (e.g. non-discrimination, denial of justice, protection against expropriation). Conceptual commonalities are particularly evident in arbitrations where investors claimed that government interferences breached both human rights and investment protections, although one arbitral tribunal declined to extend its jurisdiction beyond investment claims. ${ }^{30}$ The literature has also documented cross-fertilisation between IHRL and IIL (Fry, 2007): some arbitral tribunals have borrowed concepts from IHRL jurisprudence, particularly the proportionality test applied by the ECtHR, ${ }^{3 \mathrm{I}}$ although these instances account for a small share of arbitral case-load. Other analyses have emphasised the significant differences in normative and interpretive approaches between IHRL and IIL (Kriebaum and Schreuer, 2007; Kriebaum, 2009). In addition, there is substantial literature on potential tensions between IHRL and IIL, whether through potential (but unlikely) direct inconsistencies between IIL and IHRL norms, or potential for IIL to create a 'regulatory chill' on state action to realise human rights (Peterson and Gray, 2003). The upshot is an international legal regime shaped by forces that push towards convergence between IHRL and IIL, such as conceptual commonalities and cross-referencing in international jurisprudence, but also towards divergence, including different treaty formulations and interpretive approaches.

28 See cases cited supra note 6.

29 Centre for Minority Rights Development v. Kenya, supra note 22, para. 2 I 2.

30 Biloune and Marine Drive Complex Ltd v. Ghana Investments Centre and the Government of Ghana, Award on Jurisdiction and Liability, 27 October I989, UNCITRAL.

3I Técnicas Medioambientales Tecmed, S.A. v. United Mexican States, and Azurix Corp. v. Argentine Republic, supra note 8 . 
Building on these insights, I take a different angle, exploring the implications of the IHRL-IIL interface for commercial pressures on natural resources. This lens places rights to land and resources centre stage, and involves an analysis of how IHRL and IIL provide legal protections that can be mobilised in natural resource disputes among states claiming control over national resources, foreign investors claiming protection of concessions to exploit those resources, and indigenous peoples and rural communities asserting rights to resources having economic, social, cultural and spiritual value. Because both IHRL and IIL are internally heterogeneous, caution is needed in comparing IHRL and IIL. Overall, however, the natural resource lens reveals important fault lines between IHRL and IIL. While IHRL is based on multilateral instruments that tie the international protection of property to the recognition of the dignity of all human beings, 32 investment treaties are reciprocal arrangements that protect foreign investors and investments with the utilitarian aim of promoting economic co-operation and cross-border investments between the states parties. ${ }^{33}$ In the context of natural resource projects, IHRL and IIL tend to protect different rights: IIL would protect allocations of natural resource rights to foreign investors, while indigenous peoples and rural communities have relied on IHRL to protect their land and resource rights.

In addition, IHRL and IIL advance different concepts of property. Elsewhere I have discussed in greater depth the diverse balances of commercial and non-commercial dimensions that characterise the construction of property in IHRL and IIL (Cotula, 20I3). While many investment treaties define 'investment' in terms of assets, irrespective of their commercial or other use, arbitral tribunals have tended to emphasise the characteristics of property as a tradable asset the value of which is conceptualised in commercial and monetary terms. ${ }^{34}$ So where a piece of land is expropriated, what matters in an investor-state arbitration context is that land's contribution to the earning power of the enterprise it belonged to - a commercial farm, for example. ${ }^{35}$ This emphasis on commercial value reflects the fact that arbitral tribunals considering landed property typically deal with commercial ventures. Further, cash compensation is the main relief in investor-state arbitration, making economic valuation an important issue in arbitral proceedings.

Even in a commercial venture, however, the underlying land and natural resources may have important non-economic values, for example where investors establish or acquire commercial operations on land claimed by indigenous peoples. For these groups, the land may be a source of social identity and have important spiritual connotations, for instance in relation to sacred sites or burial grounds. These dimensions are difficult to translate in monetary terms. While the human right to property can protect commercial interests, ${ }^{36}$ IHRL does recognise the important social, cultural, spiritual and political dimensions of property, framing property in very different ways compared to IIL. For example, IHRL emphasises the close connection of collective land and

32 See e.g. the preamble of the UDHR.

33 See e.g. the preambles of Japan-Laos BIT 2008, Rwanda-US BIT 2008 and Colombia-India BIT 2009. On the reciprocal nature of investment treaties, see Standard Chartered Bank $v$. United Republic of Tanzania, Award, 2 November 20I2, ICSID ARB/Io/I2, paras. 267-270. See also Sawhoyamaxa v. Paraguay, supra note 6, para. I40, contrasting reciprocal investment treaties with multilateral human rights treaties.

34 Amoco International Finance Corp. v. Iran, supra note io, para. Io8. See also Libyan American Oil Company (Liamco) v. The Government of the Libyan Arab Republic, Award, I 2 April I977, 62 ILR I40, at I89; and Emmis v. Hungary, supra note I, paras. I65, I69.

35 Bernardus Henricus Funnekotter and Others v. Republic of Zimbabwe, Award, 22 April 2009, ICSID ARB/05/6, para. I30.

36 See the cases cited supra note 26. 
resource rights with indigenous cultures and ways of life, 37 and with the right to self-determination. ${ }^{8}$ The livelihood contribution of land, rather than its commercial value, is also the main concern in the struggles of social movements advocating for international recognition of peasants' land rights (Golay, 2013).

In addition, non-commercial considerations are prevalent in other human rights that, while not framed in property terms, have property implications. For example, where land and natural resources provide a basis for food security, protecting rights to these resources is important in realising the right to food (De Schutter, 2008, 2009). And where a government allocates a land or resource concession to an investor in ways that compress the resource rights and affect the food security of affected people, it could be violating the right to food if loss of resource rights is not compensated by durable improvements in access to alternative means for food security (Cotula, 2008; De Schutter, 20I0). Further, agrarian reform is one means for realising the right to food (ICESCR, Article I I(2)(a)). In these contexts, the protected good is access to food, rather than property itself, and what matters is the contribution of land and resources to food security, rather than their commercial value.

Fault lines between IHRL and IIL have other dimensions too, affecting the boundaries between property protection and sovereign powers. As commercial pressures on the world's natural resources increase, IIL tends to provide stricter protection standards than IHRL, with far-reaching consequences for natural resource disputes. Take the conditions for the legality of expropriations. Both IHRL and IIL condition the legality of expropriations to certain requirements. 39 Despite much variation in the formulation of investment treaties, IIL requirements typically include public purpose, non-discrimination, due process and payment of compensation, often at specified standards linking compensation to market value. $4^{\circ}$ IHRL requires broadly comparable conditions, particularly where regional systems protect the right to property (Europe, Africa and the Americas). But where effective regional systems are not in place, the IHRL protection of the right to property is severely undermined by the absence of that right in the ICCPR and the ICESCR. Even where regional systems do exist, compensation requirements are less exacting than IIL, because IHRL does not consistently link compensation to full market value. While Article I of ECHR Protocol I is silent on compensation, the ECtHR has held that compensation is implicitly required and must be 'reasonably related' to market value; however, compensation might be less than market value. ${ }^{4 I}$ Article I4 of the ACHPR affirms the right to property but does not require compensation for expropriation - it merely requires compliance with applicable law. So a breach of the national constitution would violate the ACHPR,${ }^{42}$ and many constitutional right-to-property clauses require compensation for expropriation. But, unlike IIL, the ACHPR does not address gaps that may exist in national compensation regimes.

37 E.g. Sawhoyamaxa v. Paraguay, supra note 6, paras. I I7-I I 8, I3 I; Yakye Axa Indigenous Community v. Paraguay, supra note 6, para. I35. See also art. I3(I) of the I 989 Convention Concerning Indigenous and Tribal Peoples in Independent Countries.

38 E.g. arts. 6 and I3-I9 of the I989 Convention Concerning Indigenous and Tribal Peoples in Independent Countries.

39 IHRL tackles 'interferences' with property - a broader notion than expropriation (Kriebaum, 2009). Under IIL, interferences falling short of expropriation may be covered by other standards of treatment, including fair and equitable treatment. While several human rights are relevant to the protection of property, this section only discusses the right to property.

40 See e.g. Tanzania-Italy BIT 2002, art. 5; Nigeria-South Korea BIT I997, art. 5(2); US-CAFTA 2004, art. I0.7(2); and Japan-Laos BIT 2008, art. I2(2).

$4 \mathrm{I}$ James and Others $v$. United Kingdom, supra note 2I, para. 54; Lithgow and Others $v$. United Kingdom, Judgment, 8 July I986, 8 EHRR 329, para. I2I. On ECHR jurisprudence on compensation, see Allen (20I0). 
Moreover, IIL and IHRL bodies use different analyses to establish whether a violation has occurred. In Europe, ECtHR jurisprudence is centred on the notion of a 'fair balance' that must be stuck between individual and collective interests. Applying the 'margin of appreciation' doctrine, the ECtHR has held that national governments are in principle better placed to strike that balance, and has displayed significant deference to national authorities. The ECtHR assesses public purpose and compensation in the light of that overall balance. One consequence is that the nature of the public purpose pursued may be taken into account when determining compensation. ${ }^{43}$

A stricter approach prevails in investor-state arbitrations. Most arbitral tribunals have not assessed the fairness of the overall balance between collective and investor interests - although, as discussed, a few tribunals applied a proportionality test derived from ECtHR jurisprudence. Arbitral tribunals have tended to consider that each requirement (public purpose, nondiscrimination, due process, compensation) must be fully met for an expropriation to be lawful, ${ }^{44}$ and not to balance one requirement against the other. For example, one arbitral tribunal excluded that the nature of the public purpose could justify lower compensation. ${ }^{45}$ More generally, arbitral tribunals have tended to be less deferential to national authorities: while some arbitral tribunals have referred to a 'margin of appreciation', ${ }^{66}$ most have not, and some have explicitly stated that IIL sets more stringent standards than IHRL. ${ }^{47}$ As an arbitral tribunal put it: 'Article I of the First Protocol to the European Convention on Human Rights permits a margin of appreciation not found in customary international law or the [applicable bilateral investment] Treaty.'48 As a result of these differences, the European Court and arbitral tribunals have developed different analyses of disputes ultimately arising from the same facts. ${ }^{49}$

There are other important differences between IHRL and IIL. Space constraints prevent a thorough discussion. For example, investor-state arbitral tribunals tend to award considerably higher damages than human rights courts. While exhaustion of domestic remedies is the rule under IHRL (and in Africa, access to the ACtHPR is in most cases mediated via the African Commission on Human and Peoples' Rights), most investment treaties do not condition arbitration to this requirement, providing more accessible international redress. Unlike arbitral tribunals, which issue legally binding awards, several IHRL bodies only issue non-binding decisions - including the African Commission on Human and Peoples' Rights, which, as discussed, remains the only continental IHRL body available in about half of Africa's states. And while recent years have witnessed innovation in third-country enforcement of international decisions based on human rights, $5^{\circ}$ IHRL rulings are not backed up by the multilateral instruments that

43 James $v$. United Kingdom, supra note 21, paras. 46, 54.

44 Waguih Elie George Slag and Clorinda Vecchi v. Arab Republic of Egypt, Award, I June 2009, ICSID ARB/05/I5, para. 428.

Compania del Desarrollo de Santa Elena SA v. Costa Rica, supra note io, paras. 7 I-72.

46 Continental Casualty v. Argentine Republic, Award, 5 September 2008, ICSID ARB/03/9, para. I8I.

47 Quasar De Valores SICAV S.A., Orgor De Valores SICAV S.A., GBI 9000 SICA V S.A. and ALOS34S.L. v. Russian Federation, Award, 20 July 20I2, SCC Arbitration, paras. 22-23.

48 Siemens A.G. v. Argentine Republic, Award, 6 February 2007, ICSID ARB/02/08, para. 354.

49 Contrast the different approaches followed in Roslnvest Co UK Ltd v. Russian Federation, Final Award, I 2 September 20I0, SCC Arbitration (later set aside by a Swedish court), and Quasar De Valores SICAV S. A. v. Russian Federation, supra note 47, on the one hand, and in the ECtHR case OAO Neftyanaya Kompaniya Yukos $v$. Russia, Judgment, 20 September 20I I, on the other, all relating to the same tax measures taken by the Russian government against oil company Yukos.

50 The Government of the Republic of Zimbabwe v. Fick and Others, Constitutional Court of South Africa, 27 June 20I3, Case CCT IOI/I2, allowing enforcement in South Africa of a pecuniary decision issued by the SADC Tribunal against Zimbabwe. 
facilitate the enforcement of arbitral awards. ${ }^{5 \mathrm{I}}$ These features make IIL safeguards more robust than IHRL. An important counterweight is that, while compensation is the main relief in investor-state arbitration, IHRL judgments can require states to demarcate or return property. ${ }^{22}$ However, these IHRL specific performance judgments are particularly hard to enforce against determined state resistance, and some landmark IHRL decisions have had no implementation. 53

Ultimately, neither IHRL nor IIL provides sanctuary against determined state action to interfere with property. However, in several respects IIL provides stronger protection than IHRL. Asymmetries are particularly pronounced in places not covered by effective regional human rights systems, where the IHRL protection of the right to property is at its weakest and leaves right-holders with only limited international recourse. But asymmetries also exist where regional IHRL systems apply, given differences in the conditions for the legality of expropriations (particularly compensation standards), in how these conditions are applied, and in dispute settlement and enforcement mechanisms. Due to limited space, this brief analysis of differences in property protection glosses over important dimensions. For rural communities, and particularly indigenous peoples, compensation standards are less important than requirements for free, prior and informed consent, especially where resources have important sociocultural or spiritual value - although weak compensation standards still matter because they can undermine the negotiating power of affected landholders. International instruments grant the land and resource rights of indigenous peoples particularly stringent standards of protection. As discussed, however, key instruments have had little ratification.

Asymmetries between and within IHRL and IIL have far-reaching consequences for the propertysovereignty nexus. Both IHRL and IIL presuppose state sovereignty. But they redefine the legal construction of state sovereignty - not only because, as it is often argued, the exercise of sovereign powers is increasingly regulated by international norms, but also because the nature and intrusiveness of that regulation vary depending on whose property is at stake. The different degrees of 'margin of appreciation' and the variable deference to national authorities delineate different spaces for the exercise of sovereign powers. The same government measure may be deemed lawful under IHRL and unlawful under IIL, lawful or unlawful under different investment treaties, or the same unlawful measure may attract different compensation amounts. The strategies of actors to maximise legal protection - for example, where national entrepreneurs operate through companies incorporated abroad, 54 foreign investors channel their investments through third countries, 55 or disputes rooted in the same facts are taken to multiple international tribunals $5^{6}$ - are attempts to make the most of these variable interstices between property and sovereignty. The notion of 'graduated sovereignty' (Ong, 2000) provides a fitting image for the interface between property and sovereignty under international law.

In recent years, this evolving property-sovereignty nexus has formed the object of much debate in relation to both IIL and IHRL, with variable political geographies of actors and positions: civil society has advocated defending sovereign space from IIL encroachment, but also relied on IHRL

5I Namely, the I958 Convention on the Recognition and Enforcement of Foreign Arbitral Awards and arts. 53-55 of the I965 ICSID Convention.

52 E.g. Mayagna (Sumo) Awas Tingni Community v. Nicaragua, supra note 6, para. 173.3-4, and Sawhoyamaxa Indigenous Community v. Paraguay, supra note 6, para. 248.6, respectively.

53 E.g. African Commission on Human and Peoples' Rights, Resolution Calling on the Republic of Kenya to Implement the Endorois Decision, 5 November 2013, online: 〈http://www.achpr.org/sessions/54th/resolutions/257/〉.

54 Tokios Tokeles v. Ukraine, Decision on Jurisdiction, 29 April 2004, ICSID ARB/O2/I8.

55 For example Saluka Investments BV v. Czech Republic, Partial Award, I7 March 2006, UNCITRAL, paras. $222-244$.

56 See e.g. the cases cited supra note 49. 
to challenge sovereign acts deemed to violate the land and resource rights of indigenous peoples and rural communities. These dynamics reflect the different rationales of IHRL and IIL (protecting human dignity, promoting investment flows), and highlight the complexities of the interplay between the commercial and human rights dimensions of the relationship between property protection and graduated sovereignty. The practical implications of these complexities are apparent where different claims to natural resources come directly into contest - an issue I now turn to discussing.

\section{International law and struggles over land and natural resources}

The systemic considerations about asymmetries in legal protection and the property-sovereignty interface affect the role of international law in addressing pressures on land and natural resources - for example, where a government allocates commercial concessions in areas claimed by indigenous peoples or rural communities, or where land restitution or redistribution claims target property held by foreign investors. In these contexts, indigenous peoples and rural communities have relied on IHRL to protect their rights, for instance to contest the award of natural resource concessions. ${ }^{57}$ On the other hand, foreign investors can rely on IIL standards on expropriation or fair and equitable treatment to challenge government action that, while responding to local demands, adversely affects business prospects. ${ }^{8}$ Where these multiple normative sources are mobilised, differentiated protections under IHRL and IIL affect the role of international law in struggles over natural resources.

International law disputes over natural resources involving direct tensions between IHRL and IIL remain few. But this should not deceive us into dismissing the issue as unimportant (see Simma, 20II, pp. 578-579). In the coming years, the growing pressures on the world's resources, and growing recourse to international law in a globalised world, will arguably tend to increase the likelihood of these disputes. Human rights jurisprudence on ancestral land restitution claims provides insights on what these disputes might look like. In Sawhoyamaxa v. Paraguay, an indigenous community claimed restitution of their ancestral lands. The Paraguayan government resisted restitution, arguing that the claim 'collides with a property title which has been registered', lastly with a German investor protected under the Germany-Paraguay BIT. The suggestion was that land restitution would infringe upon the investor's property, breaching the investment treaty. 59 In its 2006 Judgment, the IACtHR noted that the investment treaty did not prohibit expropriation - it merely subjected its legality to certain conditions, including public purpose; ${ }^{60}$ that land restitution aimed at realising the right to property of indigenous peoples could constitute public purpose; and that investment treaties must be applied consistently with IHRL. ${ }^{6 I}$ The IACtHR ordered land restitution within three years. In 20I4, after twenty-three years of legal wrangling, Paraguay passed a law providing for the expropriation of the land and its restitution to the Sawhoyamaxa community. ${ }^{62}$ Time will tell whether the implementation of this law will give rise to investor-state arbitration claims, and with what consequences.

57 E.g. Mayagna (Sumo) Awas Tingni Community v. Nicaragua, supra note 6.

58 E.g. Técnicas Medioambientales Tecmed, S.A. v. United Mexican States, supra note 8.

59 Sawhoyamaxa Indigenous Community v. Paraguay, supra note 6, paras. I I5(b), I25, I37.

60 Germany-Paraguay BIT I993 (art. 4(2)), not directly read or cited by the ACtHR.

6I Sawhoyamaxa Indigenous Community v. Paraguay, supra note 6, para. I40.

62 Law No. 5I94 of I2 June 20I4, online: 〈http://www.tierraviva.org.py/wp-content/uploads/20I4/o6/GacetaSawhoyamaxa.pdf>. 
Recent developments provide several examples of natural resource disputes mobilising IHRL and/ or IIL. Investor-state arbitrations have dealt with extractive industry projects that impacted on lands having spiritual value for indigenous peoples, who raised IHRL issues in amicus curiae submissions. ${ }^{6}$ Investors have referred to investment treaties in national litigation to challenge land expropriation for redistribution, ${ }^{64}$ and Zimbabwe's controversial land reform programme has resulted in three known investor-state arbitrations. ${ }^{65}$ After the Colombia-UK BIT 20Io came into force in 20I4, civil society raised concerns that indigenous peoples' ongoing land restitution claims overlapping with mining concessions in Colombia might face more uncertain prospects. ${ }^{66}$

The Sawhoyamaxa Judgment suggests that international tribunals are likely to seek to reconcile different normative sources by articulating interpretations that facilitate consistency between obligations under different treaties. Yet, where states have invoked human rights obligations as a defence for alleged investment treaty violations in investor-state arbitration contexts, some tribunals have appeared reluctant to consider human rights arguments (Hirsch, 2009). For example, two arbitral tribunals refused to consider human rights arguments raised by Argentina, deeming these arguments not to have been sufficiently elaborated. ${ }^{67}$ Moreover, the question remains as to what would happen if an investor and people affected by the investment were to bring parallel cases to investor-state arbitration and IHRL bodies, respectively. In recent years, indigenous peoples and local communities have filed several requests for precautionary measures with the Inter-American Commission of Human Rights in relation to evictions and land degradation associated with mining projects and hydroelectric developments (Hepburn, 20I2). In at least one case, human rights proceedings were initiated in parallel to an ongoing investor-state arbitration, though petitioners later withdrew their application to the Inter-American Commission (Hepburn, 20I2). Such suits could bring the protection of property under IHRL and IIL directly into tension.

At one level, tensions between IHRL and IIL could be said to be primarily about the distribution of costs: states do have the sovereign right to take measures to protect or restore the property of disadvantaged groups, but they must compensate foreign investors for losses suffered. The state, not the investor, should bear the costs. The Sawhoyamaxa case points in this direction. Arguably, however, the practical implications can be more far-reaching. IIL requirements for states to compensate investors at full market value can raise real questions where investors acquired resource rights at below-market rates, for example from a previous authoritarian government (Bonnitcha, 20I4). And, at scale, applying these requirements without considering historical injustices that may have occurred, and without the flexibility on compensation allowed by IHRL (compensation related to market value, but not necessarily equivalent to it; nature of the public purpose potentially affecting compensation), can make it very costly for states to redistribute or restitute land, or to change policy affecting natural resource investments. The large compensation

63 Glamis Gold Ltd. v. United States of America, Award, I4 May 2009, UNCITRAL, particularly paras. 83-84 of the Award and Application for Leave to File a Non-Party Submission and Submission of the Quechan Indian Nation, I9 August 2005, online: 〈http://www.state.gov/documents/organization/5253I.pdf〉.

64 Günter Kessl, Heimaterde CC and Martin Joseph Riedmaier v. Ministry of Lands and Resettlement and Others, High Court of Namibia, Judgment, 6 March 2008, paras. 24, I06-I07.

65 Bernardus Henricus Funnekotter and Others v. Republic of Zimbabwe, supra note 35, and the ongoing parallel arbitrations Bernard Von Pezhold and Others v. Zimbabwe and Border Timbers Limited, Border Timbers International (Private) Limited, and Hangani Development Co. (Private) Limited v. Republic of Zimbabwe, ICSID, online: 〈http://www.italaw.com/cases/I472〉.

66 Personal communication, November 20I4.

67 Azurix Corp. v. Argentine Republic, supra note 8, paras. 254, 26I; Siemens A.G. v. Argentine Republic, supra note 48, paras. 75, 79. Neither case concerns natural resource investments. 
amounts awarded through investor-state arbitration can raise challenges, especially in lower-income countries where public finances are constrained. Reports that even developed country governments hold back from enacting legislation capable of adversely affecting foreign investment due to concerns about arbitration claims suggest that informed governments factor liability risks into decisionmaking. ${ }^{68}$

Because of the significant financial implications of arbitration claims, the more stringent standards of protection under IIL could skew incentives for public action, effectively encouraging states to prioritise property claims associated with foreign investment over the rights of indigenous peoples and rural communities. Where states do not wish to take measures favouring disadvantaged groups due to the interplay of vested interests and power relations, asymmetries in international protection could provide governments with legal arguments to legitimise political choices. And where negotiations occur among government, foreign investors and rural communities, differentiated legal protections could affect the balance of negotiating power, influencing decision-making on land and natural resources (see Cotula, 2012).

The actual extent of these phenomena is an empirical question requiring further study. In principle, however, these multiple channels can connect the distribution of costs to substantive enjoyment of rights. The variable boundaries of graduated sovereignty can have practical implications for the role of international law in managing pressures on natural resources. Should a pattern emerge whereby systemic features of international law favour the property claims associated with foreign investment over the rights of the world's poorest and most marginalised people, important issues would arise about social justice and ultimately about the perceived legitimacy of international law.

\section{Towards greater systemic coherence and citizen participation}

Long at the margins of international law debates, the conceptualisation and regulation of property are now among the key challenges facing international law- and decision-makers. A 'shrinking' planet and a polycentric international legal regime provide the backdrop for contestation between different ways to conceptualise property - as a commercial asset, or a basis for sociocultural relations. Rapid evolutions in treaty-making and growing use of international redress mechanisms are redefining the boundaries for the lawful exercise of state sovereignty, and shifting the balance of commercial and non-commercial considerations in property disputes. Investors have challenged adverse government action through investor-state arbitration. Faced with growing commercial pressures on the resources they claim, indigenous peoples and rural communities have also resorted to legal action, often as part of wider mobilisation strategies, even in contexts where citizens have traditionally displayed little trust in the formal justice system. But increased resource competition is occurring in a legal context in which different sets of rights enjoy differentiated legal protection, with important repercussions for the role of international law in struggles over land and natural resources.

This analysis raises systemic issues about the contours of state sovereignty in the international legal order. And the notion of graduated sovereignty intersects the vast and complex debate about unity and fragmentation in international law, which cannot be engaged here. Suffice to say that fragmentation in the rules applicable to different actors, places and situations is not necessarily incompatible with some deeper-level unity of international law. However, the familiar repertoire of conflict-of-norms techniques discussed in the International Law Commission (ILC) study on

68 For example, in 2013 the government of New Zealand reportedly announced that it would wait to see the outcome of an arbitration brought by a global tobacco firm against Australia before enacting anti-smoking legislation (Peterson, 2013). 
fragmentation (lex specialis, lex posterior, lex superior, and 'systemic integration' based on Article $3 \mathrm{I}(3$ ) (c) of the Vienna Convention on the Law of Treaties) offers limited help in addressing the issues raised in this paper. ${ }^{69}$ These techniques can assist an international tribunal in reconciling conflicting norms of international law: they define which norm should prevail, or how two apparently conflicting norms can be interpreted in constructive ways. But they are of more limited use in situations where disputes are taken to several international tribunals having jurisdiction to apply different bodies of international law, for example. The relationship between IHRL and IIL cannot be conceptualised in terms of lex specialis or lex posterior, and few would argue that IHRL norms on the protection of property constitute jus cogens. Systemic integration is the most relevant tool, as it may allow an arbitral tribunal deciding on a natural resource investment dispute to consider 'relevant' IHRL obligations in the interpretation of an investment treaty (Dupuy, 2009; Simma, 20II). In a frictionless world, systemic integration would be expected to result in IHRL and IIL tribunals reaching similar conclusions on disputes rooted in the same facts. In practice, however, this outcome should not be taken for granted - not least because systemic integration leaves considerable discretion to decision-makers (Simma, 20II), for instance on how a treaty is 'taken into account' in the interpretation of another treaty, creating uncertainty on the outcomes of separate but interlinked IHRL and IIL disputes.

In practice, the most powerful force behind convergence between IHRL and IIL has so far been the borrowing of legal concepts and interpretive approaches between arbitral tribunals and IHRL bodies - well beyond the confines of Article 3I(3)(c) of the Vienna Convention, which only refers to rules applicable 'in relations between the parties'. ${ }^{70}$ Some authors have seen promise in this normative cross-fertilisation, for example in relation to the proportionality test (Schill, 2012), and several actions can encourage cross-fertilisation: segmented epistemic communities are an important barrier, and much can be gained from more communication across academic disciplines (Kriebaum and Schreuer, 2007); the wording of different treaties can facilitate, or constrain, borrowing between branches of international law, so drafters can play an important role; and dismissal of human rights claims by arbitral tribunals on grounds of poor argumentation suggests that there is room for strengthening government capacity to articulate human rights arguments in an arbitration context.

Ultimately, however, the different rationales and wordings of IHRL and IIL treaties create important limits to cross-fertilisation. Moreover, proportionality leaves much discretion to decision-makers, and some human rights lawyers would feel uncomfortable about the ways in which arbitral tribunals might balance human rights and investment protection considerations. Further, an exclusive focus on substantive norms neglects the importance of institutional aspects - largely left unaddressed by the ILC study. Tenured human rights judges and one-off investment arbitrators may have different mindsets and expertise, and respond to different incentives (Van Harten, 2007), so their application of the same legal test might well lead to different outcomes. In a context of growing pressures on resources, what the analysis of differentiation in the IHRL and IIL protection of property does point to is a need to carefully think through choices on whether to conclude investment treaties, and on multiple drafting options for these treaties; and significantly to strengthen the protection available under IHRL (substantive standards, legal remedies). Stronger IHRL protection could be achieved not only though new treaties that are difficult to negotiate and

69 'Fragmentation of International Law: Difficulties arising from the Diversification and Expansion of International Law', Report of the Study Group of the International Law Commission, I3 April 2006, A/ CN.4/L.682. Art. 3I(3)(c) of the Vienna Convention requires a tribunal interpreting a treaty to take into account '[a]ny relevant rules of international law applicable in the relations between the parties'.

70 References to ECtHR jurisprudence in Tecmed and Azurix, supra note 8, involved arbitrations in which at least one state was not a party to the ECHR. 
implement, but also through interpretation and application that push the boundaries of existing treaties. ${ }^{71}$

These issues have important political dimensions, because ultimately at stake is whose rights should be protected, how to balance private property and the public good, and the legal construction of national sovereignty. This political dimension raises the issue of democratic participation in decision-making processes, linking the relationship between property protection and sovereign space to active citizenship - broadly defined here in political, non-legalistic terms as the active participation in the management of public affairs (Gaventa, 2002). The relationship between property and citizenship is complex and multifaceted (see Lund, 20Irb). Historically, a close connection existed in the European liberal states, where landed property was infamously a precondition for political suffrage. But this connection emerges in other ways and contexts too. The international protection of the land and resource rights of indigenous peoples links property to self-determination. Constitutional right-to-property clauses often constitute an important part of the social contract. And the fact that foreign investors do not enjoy formal political representation in the host state has long been used as an argument to justify the special protection of foreign property under $\mathrm{IIL}^{72}$ - although this formalistic view of political influence does not reflect the multiple real-world channels that both foreign and domestic companies can use to affect policy even if they cannot vote.

Yet developments in international law also epitomise breakdowns in the relationship between property and citizenship. Investment treaties often grant foreign investors stronger property protection than that available to citizens, but are often concluded with little citizen oversight, particularly in low- and middle-income countries. On the IHRL side, non-governmental organisations and social movements have been reluctant to engage with the right to property, which many perceive to protect 'the rich and powerful' (Van Banning, 2002, p. 7), even though IHRL jurisprudence has shown the gains that can be achieved through effective use of the collective right to property. There are signs that this situation is changing. Public scrutiny of investment treaties and arbitration is increasing. Greater reliance on the right to property by indigenous and tribal peoples, and invocation of a 'right to land' by peasant movements, reflect growing citizen appropriation of the international mechanisms to protect property. Today, fault lines and transitions in the conceptualisation of property call for citizens to step up efforts to have their voices heard in the development of international law.

\section{References}

ALlen, Tom (2010) 'Liberalism, Social Democracy and the Value of Property Under the European Convention on Human Rights', International and Comparative Law Quarterly 59(4): 1055-1078. BARnes, Richard (2009) Property Rights and Natural Resources. Oxford and Portland, OR: Hart Publishing. BONNITCHA, Jonathan (20I4) 'Investment Treaties and Transition from Authoritarian Rule', Journal of World Investment and Trade I5(5/6): 965-IOI I.

CHRISTIE, George C. (1963) 'What Constitutes a Taking of Property Under International Law?' British Yearbook of International Law 38: 307-338.

cotula, Lorenzo (2008) 'The Right to Food and Resource Access - Conceptual Links', in Lorenzo Cotula (ed.), The Right to Food and Access to Natural Resources - Using Human Rights

7 I For example, while art. I of ECHR Additional Protocol I is silent on compensation, the ECtHR held this to be an implicit requirement (James $v$. United Kingdom, supra note $2 \mathrm{I}$, para. 54), and it is now well established that the ECHR requires payment of compensation related to market value.

72 See the ECtHR case James v. United Kingdom, supra note 2 I, para. 63, and the investor-state arbitration Joseph Charles Lemire v. Ukraine, Award, 28 March 20I I, ICSID ARB/o6/I 8, para. 57. 
Arguments and Mechanisms to Improve Resource Access for the Rural Poor. Rome: Food and Agriculture Organization of the UN, online: 〈http://www.fao.org/docrep/or6/k8093e/k8093e.pdf〉, I 2-35. cotula, Lorenzo (20I2) Human Rights, Natural Resource and Investment Law in a Globalised World: Shades of Grey in the Shadow of the Law. London and New York: Routledge.

cotula, Lorenzo (2013) 'The New Enclosures? Polany, International Investment Law and the Global Land Rush', Third World Quarterly 34(9): I605-1629.

DE SCHUTTER, Olivier (2008) Report of the Special Rapporteur on the Right to Food, 2I October 2008, UN Doc. A/63/278, online: 〈http://www.srfood.org/images/stories/pdf/officialreports/or-2ungareporta63278en.pdf>.

DE SCHUTter, Olivier (2009) Large-Scale Land Acquisitions and Leases: A Set of Minimum Principles and Measures to Address the Human Rights Challenge. Addendum to the Report of the Special Rapporteur on the Right to Food, 28 December 2009, UN Doc. A/HRC//13/33/Add, online: <http:// www.srfood.org/images/stories/pdf/officialreports/20100305_a-hrc-I3-33-add2_land-principles_en. pdf $>$.

DE SCHUTTER, Olivier (20I0) 'The Emerging Human Right to Land', International Community Law Review I 2: $303-334$.

DOLzer, Rudolf (I 986) 'Indirect Expropriation of Alien Property', ICSID Review - Foreign Investment Law Journal I: 4I-65.

Douglas, Zachary (2009) The International Law of Investment Claims. Cambridge: Cambridge University Press.

Douglas, Zachary (2014) 'Property, Investment and the Scope of Investment Protection Obligations', in Zachary Douglas, Joost Pauwelyn and Jorge E. Viñuales (eds), The Foundations of International Investment Law: Bringing Theory into Practice. Oxford: Oxford University Press, 363-408.

DUPUY, Pierre-Marie (2009) 'Unification Rather than Fragmentation of International Law? The Case of International Investment Law and Human Rights Law', in Pierre-Marie Dupuy, Francesco Francioni and Ernst-Ulrich Petersmann (eds), Human Rights in International Investment Law and Arbitration. Oxford: Oxford University Press, 45-62.

EDERINGton, L. Benjamin (I997) 'Property as a Natural Institution: The Separation of Property from Sovereignty in International Law', American University International Law Review I3: 263-33 I.

FaundeZ, Julio (2010) 'International Economic Law and Development: Before and After Neoliberalism', in Julio Faundez and Celine Tan (eds), International Economic Law, Globalization and Developing Countries. Cheltenham: Edward Elgar, Io-33.

FRANCIONI, Francesco (2009) 'Access to Justice, Denial of Justice, and International Investment Law', in Pierre-Marie Dupuy, Francesco Francioni and Ernst-Ulrich Petersmann (eds), Human Rights in International Investment Law and Arbitration. Oxford: Oxford University Press, 63-8I.

FRY, James D. (2007) 'International Human Rights Law in Investment Arbitration: Evidence of International Law's Unity', Duke Journal of Comparative and International Law I8: 77-I49.

García-AMADOR, Francisco V. (1955) 'State Responsibility in the Light of the New Trends of International Law', American Journal of International Law 49: 339-346.

GAVENTA, John (2002) 'Introduction: Exploring Citizenship, Participation and Accountability', IDS Bulletin 33(2): I-I I.

GOLAY, Christophe (2013) 'Legal Reflections on the Rights of Peasants and Other People Working in Rural Areas: Background Paper Prepared for the First Session of the Working Group on the Rights of Peasants and Other People Working in Rural Areas.' Geneva: Office of the High Commissioner for Human Rights, online: <http://www.ohchr.org/Documents/HRBodies/ HRCouncil/WGPleasants/Golay.pdf>.

HEPBURN, Jarrod (20I2) 'Analysis: Interim Measures Granted by Inter-American Commission Have Featured in Several Recent Investment Controversies', IAReporter, online: <http://www. iareporter.com/articles/20I203I4_I >. 
HIRSCH, Moshe (2009) 'Investment Tribunals and Human Rights: Divergent Paths', in PierreMarie Dupuy, Francesco Francioni and Ernst-Ulrich Petersmann (eds), Human Rights in International Investment Law and Arbitration. Oxford: Oxford University Press, 97-I I4.

ICSID (2013) The ICSID Caseload - Statistics. Washington DC: International Centre for Settlement of Investment Disputes, Issue 20I3-2, online: 〈https://icsid.worldbank.org/ICSID/FrontServlet? requestType=ICSIDDocRH\&actionVal=CaseLoadStatistics $>$.

JAYASURIYA, Kanishka (I999) 'Globalization, Law and the Transformation of Sovereignty: The Emergence of Global Regulatory Governance', Indiana Journal of Global Legal Studies 6(2): 425-455. KRIEBAUM, Ursula (2009) 'Is the European Court of Human Rights an Alternative to Investor-State Arbitration?', in Pierre-Marie Dupuy, Francesco Francioni and Ernst-Ulrich Petersmann (eds), Human Rights in International Investment Law and Arbitration. Oxford: Oxford University Press, 2I9-245.

kriebaum, Ursula and schreuer, Christoph (2007) 'The Concept of Property in Human Rights Law and International Investment Law', in Stephan Breitenmoser (ed.), Liber Amicorum Luzius Wildhaber, Human Rights Democracy and the Rule of Law, online: <http:/www.univie.ac.at/intlaw/wordpress/ pdf/88_concept_property.pdf >, 743-762.

KROHNKE, Duane W. (2013) 'Failed Efforts to Weaken the Inter-American Human Rights System under the Guise of Reform', blog entry, 26 March, online: 〈http://dwkcommentaries.com/2013/03/26/ failed-efforts-to-weaken-the-inter-american-human-rights-system-under-the-guise-of-reform/>. LESAFFER, Randall (2005) 'Argument from Roman Law in Current International Law: Occupation and Acquisitive Prescription', European Journal of International Law I6(I): 25-58.

LOCKE, John (2010 [1689]) Two Treatises of Government, Second Treatise of Government, online: <http:// www.gutenberg.org/files/7370/7370-h/7370-h.htm >.

LUnd, Christian (201 Ia) 'Fragmented Sovereignty: Land reform and Dispossession in Laos', Journal of

Peasant Studies 38(4): 885-905.

Lund, Christian (20IIb) 'Property and Citizenship: Conceptually Connecting Land Rights and Belonging in Africa', Africa Spectrum 46(3): 7 I-75.

nathan, Laurie (2013) 'The Disbanding of the SADC Tribunal: A Cautionary Tale', Human Rights Quarterly 35: 870-892.

NICHOLson, Francis J. (I965) 'The Protection of Foreign Property under Customary International Law', Boston College Law Review VI(3): 39I-4I5.

ONG, Aihwa (2000) 'Graduated Sovereignty in South-East Asia', Theory Culture Society I 7: 55-75.

Pennington, Kenneth (I993) The Prince and the Law, I200-I60o: Sovereignty and Rights in the Western Legal Tradition. Berkeley and Los Angeles: University of California Press.

PETERSON, Luke Eric (2013) 'First Hearing in Philip Morris v. Australia Arbitration is Pushed into 2014, as New Zealand Reveals it is Awaiting Outcome of Australian Cases', IAReporter, online: <http:// www.iareporter.com/articles/20130228_2>.

PETERSON, Luke Eric and GRAY, Kevin R. (2003) International Human Rights in Bilateral Investment Treaties and in Investment Treaty Arbitration. Winnipeg: International Institute for Sustainable Development, online: 〈http://www.iisd.org/pdf/2003/investment_int_human_rights_bits.pdf〉. REINISCH, August (2008), Legality of Expropriation', in August Reinisch (ed.), Standards of Investment Protection. Oxford: Oxford University Press, I7 I-204.

SASSEN, Saskia (2000) 'The State and Economic Globalization: Any Implications for International Law?', Chicago Journal of International Law I(I): I09-I I6.

schill, Stephan W. (2009), The Multilateralization of International Investment Law, Cambridge: Cambridge University Press.

schill, Stephan W. (20I2) 'Cross-Regime Harmonization Through Proportionality Analysis: The Case of International Investment Law, the Law of State Immunity and Human Rights', ICSID Review Foreign Investment Law Journal 27: 87-I I9. 
SCHRIJVER, Nico (2000) 'The Changing Nature of State Sovereignty', British Yearbook of International Law, $65-98$.

scolnicov, Anat (2013) 'Lifelike and Lifeless in Law: Do Corporations Have Human Rights?' University of Cambridge Faculty of Law Research Paper No. I3/2013, online: 〈http://ssrn.com/abstract= 2268537>.

SHELton, Dinah (2014) 'The Rules and the Reality of Petition Procedures in the Inter-American Human Rights System', George Washington University Law School, The Future of the Inter-American Human Rights System Working Paper No. 2, online: 〈http://humanrights.nd.edu/assets/134027/ sheltonia.pdf〉.

SImma, Bruno (20I I) 'Foreign Investment Arbitration: A Place for Human Rights?', International and Comparative Law Quarterly 60(3): 573-596.

SPRANKLING, John G. (20I4) 'The Global Right to Property'. Online: Columbia Journal of Transnational Law 52: 464-505.

UnCTAD (2012) Expropriation. Geneva and New York: United Nations Conference on Trade and Development.

valenCia RODríguez, Luís (I993) The Right of Everyone to Own Property Alone as Well as in Association with Others: Completed Final Report, United Nations Commission on Human Rights, U.N. Doc. E/CN.4/ I994/I9.

van banning, Theo R. G. (2002) The Human Right to Property. Cambridge and Morsel: Intescentia. van Harten, Gus (2007) Investment Treaty Arbitration and Public Law. Oxford: Oxford University Press. 